\title{
FİZİKSEL AKTİVİTE VE SAĞLIKLI BESLENMENİN BİLİŞİM SEKTÖRÜNDE MASA BAŞINDA ÇALIŞANLARIN SAĞLIĞINA ETKİLERİNİN DEĞERLEMESİ (1)
}

BURCU GÜVEN (2)

\begin{abstract}
öz
Bu çalıșmada son yıllarda ișyeri koșullarının değișimi ve sağlığı koruma yerine geliștirme ile birlikte ortaya çıkan fiziksel aktivite ve sağlıklı beslenme hizmetleri ele alınmıştır. Bu kapsamda bilișim sektöründe masa bașında çalıșanlara yönelik fiziksel aktivite ve sağlıklı beslenme bağlamında yönetsel faaliyetlerin bilișim sektöründe masa bașında çalıșanların sağlığına etkisi araștırılmıștır. Araștırmanın uygulama alanı İstanbul bölgesinde yer alan bilișim sektöründeki büyük ölçekli ișletmelerdir.
\end{abstract}

Araștırmanın sonucunda elde edilen veriler faktör analizine tabi tutulmuș, ișyeri ortamı ve yönetsel faaliyetlerle ilgili olan faktörler ile çalıșan sağlığı arasında korelasyon ve çoklu regresyon analizleri yapılmıștır. İșyeri sağlık iklimi, ișyeri sağlık kültürü ve çalışanların yönlendirilmesiyle ilgili olan bu değișkenler ile bulgular yorumlanmıștır.

Anahtar Kelimeler: Fiziksel aktivite, İșyeri sağlık iklimi, İşyeri sağlık kültürü, Masa başında çalıșanlar, Sağlıklı beslenme

JEL Kodları: M12

\section{ABSTRACT}

In the research with the changes occurred in the working conditions, the perception of the concept of health phsyical activity and healthy nutrition are studied within the context of employee health promotion services. In the methodological part of the research, the effects of physcial activity and healthy nutrition on sedentary workers' health have been assessed in information technology sector.

1 Bu makale 10-12 Mayıs 2012 tarihinde gerçekleșen 11.Ulusal İșletmecilik Kongresi'nde sunulan “Fiziksel Aktivite ve Sağlıklı Beslenmenin Masa Bașında Çalıșanların Sağlığına Etkilerinin Değerlemesi ve Bilișim Sektörüne Yönelik Bir Uygulama” bașlıklı tebliğin geliștirilmiș halidir.

2 Öğr. Gör. Dr., Beykoz Lojistik Meslek Yüksekokulu, burcuguvenabeykoz.edu.tr 
The data obtained from the research are first analysed with the help of factor analysis. In addition, the findings of the factor analysis related to worksite health climate, managerial activities and their effects on the employee health are analysed with corelation and multiple regression analysis methods. These variables and findings regarding worksite health climate, worksite health culture and the coordination of the employee in the services are interpreted.

Keywords: Healthy nutrition, physical activity, sedentary workers, worksite health climate, worksite health culture

JEL Codes: M12 


\section{Giriș}

Gelișmiş ülkelerin ekonomik güçlerinin kaynağı sanayi devrimi dönemlerinde endüstriye dayanırken günümüzde bilgiye sahip olan ülkeler bir adım önde olmaktadır. Bu değișimlere bağlı olarak gelișmiș ülkelerde öne çıkan sektörlerin hizmet üreten, bilgi kullanımı ağırlıklı, bilișim sektörünün de içinde yer aldığı üçüncül sektörler olduğu görülmektedir (Mütercimler, 2006: 67). Ekonomide görülen bu değișimler, çalıșma koșullarının değișimine neden olarak bedensel emeğin kullanımından ziyade zihinsel emeğin kullanımına neden olmaktadır. İsyerleri yașanan bu değișimler ile birlikte fabrikadan ofise dönüșmekte, çalıșanlar mesai saatleri süresince ofislerde masa bașında, bilgisayar karșısında minimum hareket, maksimum zihin emeği ile çalıșmaktadırlar.

Çalıșanlar yalnızca çalıșma hayatında hareketsizlik ile karşı karşıya kalmamakta, gündelik hayatta teknolojik dönüșümler ile gelen yenilikler de hareketsizliği arttırmaktadır. Gelișen teknolojinin yanı sıra zaman sıkıntısı, büyük șehirlerdeki yașam biçimlerinin getirdiği değișiklikler beslenme alıșkanlıklarını değiștirmektedir. Yașam biçimlerindeki değișimlerin etkilediği bir diğer konu ise ölüm nedenleridir. Türkiye'de ölümlerin en önemli nedeni kalp-damar rahatsızlıklarıdır. Kalp-damar rahatsızlıklarının ardından kanser gelmektedir (Sağlık Bakanlığı, 2010: 20). Bu rahatsızlıkları hareketsizlik ve sağlıksız beslenme doğrudan etkilemektedir. Bu değișimlerin yanı sıra sağlık kavramının tanımı ile ilgili gerçekleșen dönüșümler, sağlığın korunması yerine geliștirilmesi yönündeki bakıș açısının yerleșmesi, sağlıklı olmanın üst sınırının olmaması fiziksel aktivite (FA) ve sağlıklı beslenme (SB) gibi sağlığı geliștirici hizmetleri ortaya çıkarmıștır. Günümüzde ișletmelerin çalıșan sağlığı ile ilgili olușturdukları politikaları düzenlerken bu faktörleri dikkate almaları gerekmektedir.

Türkiye' de 2010 yılından itibaren Sağlık Bakanlığı ve çeșitli ilaç firmalarının, derneklerin ve vakıfların yürüttükleri kampanyalar ile toplum, sağlıklı beslenme ve fiziksel aktivite konusunda bilinçlendirilmeye çalıșılmaktadır. Türkiye'nin gelișmiș ülkelerle ekonomik anlamda yarıșabilmesi, onlarla aynı platformlarda yer alabilmesi ve toplumun refahı için yalnızca sosyal güvenlik sistemlerindeki değișimlerin yeterli olmayacağı daha pratik çözümlere de gereksinim duyulduğunun FA ve SB hizmetlerinin uygulamaları ile anlasılması gerekmektedir.

\section{Araștırma}

Araștırmada, 5 adet ana ve 2 adet demografik hipotez toplanan veriler ve kullanılan analiz yöntemleri ile test edilmiștir. 


\subsection{Araștırmanın Modeli}

Araștırmada bağımlı değișkenler ve bağımsız değișken arasındaki değerlendirmeyi yapabilmek amacıyla așağıdaki hipotezler olușturulmuștur.

\section{Araștırmanın Hipotezleri}

$\mathrm{H}_{1}$ : İşyeri ortamının sağlıklı beslenme ve fiziksel aktivite için uygunluğu ile çalıșan sağlığı arasında ilișki vardır.

$\mathrm{H}_{2}$ : İșletmenin sağlıklı beslenmeye verdiği önem ve yönlendirme ile çalıșan sağlığı arasında ilișki vardır.

$\mathrm{H}_{3}$ : İșletmenin fiziksel aktiviteye verdiği önem ve yönlendirme ile çalıșan sağlığı arasında ilișki vardır.

$\mathrm{H}_{4}$ : İșletme çalıșanlarının fiziksel aktiviteye verdiği önem ve yönlendirme ile çalıșan sağlığı arasında ilișki vardır.

$\mathrm{H}_{5}$ : İșletme çalıșanlarının sağlıklı beslenmeye verdiği önem ve yönlendirme ile çalıșan sağlığı arasında ilișki vardır.

\section{Demografik Özellikler ile Ilgili Hipotezler}

$\mathrm{H}_{6}$ : Cinsiyet ile sağlık durumu arasında ilișki vardır.

$\mathrm{H}_{7}$ : Çalıșanların medeni durumu ile sağlık durumları arasında ilișki vardır.

Araștırma kapsamında belirlenen hipotezlere bağlı olarak “İşyeri Ortamının Sağlıklı Beslenme ve Fiziksel Aktivite İçin Uygunluğu”, “İșlemenin Fiziksel Aktiviteye Verdiği Önem ve Yönlendirme”, “İșletmenin Sağlıklı Beslenmeye Verdiği Önem ve Yönlendirme”, “İșletme Çalıșanlarının Fiziksel Aktiviteye Verdikleri Önem”, “İșletme Calıșanlarının Sağlıklı Beslenmeye Verdiği Önem”, incelenmiș ve her bir boyutun çalıșanların sağlığı üzerindeki görece etkisi karșılaștırmalı olarak sorgulanmıștır. Araștırmada belirlenen hipotezleri test edebilmek için iki ölçeğe bașvurulmuștur. Araștırmanın ölçeklerinden biri Mazzola'nun 2010 yılında geliștirdiği “İşyeri Fiziksel Aktivite Ve Beslenme İklimi” ölçeğidir (Mazzola, 2010: 90-5). Bu ölçekte kullanılan Likert ölçeği 1'den 5'e kadar , “Hiç Katılmıyorum”, “Kısmen Katılıyorum”, “Orta Düzeyde Katılıyorum”, “Büyük Ölçüde Katılıyorum”, “Tümüyle Katılıyorum” ifadelerini içermektedir.

Araștırmada kullanılan diğer ölçek ise Hege R. Eriksen, Camilla Ihlebak ve Holger Ursin tarafından geliștirilen “Sübjektif Sağlık Șikâyetleri” ölçeğidir. 28 farklı sağlık șikâyetinin yer aldığı ölçekte çalıșanlardan her bir sağlık problemini son bir ayda yașama durumlarını, hangi șiddette yașadıklarını ve söz konusu problemin ne kadar sürdüğünü belirtmeleri istenmiștir ( Eriksen vd. , 2002: 20-9). Hastalığın șiddetinin ölçülmesinde “Hiç”, “Hafif Düzeyde”, “Orta” ve “Ciddi” olmak üzere dörtlü Likert ölçeğinden yararlanılmıștır. 
Ölçeklerin yabancı dilden çevrilmesinden ve geçerlilik ile ilgili yașanabilecek olan sıkıntıları giderebilmek adına iki ölçekte tüm sorular kullanılmıș, soruların çevirisi yapılırken çeviri biliminden bir uzman, bir Türk dili ve edebiyatı uzmanı ile ișletme bilimi uzmanlarının görüșlerine bașvurulmuștur.

\subsection{Araștırmanın Amacı}

Araștırmanın amacı, bilișim sektöründeki ișletmelerde FA ve SB’ye yönelik hizmetler ile ilgili yürütülen yönetsel faaliyetlerin çalıșan sağlığına etkilerini ortaya koymaktır. Uygulamada kullanılan ölçeklerde, çalıșanların FA ve SB'ye yönlendirilmesinin, ișletmenin hizmetlere verdiği önemin ve ișyerinde hizmetler için uygun çevresel koșullar olușturulmasının çalıșan sağlığına etkilerinin değerlemesi araștırılmaktadır.

\subsection{Anakütle ve Örneklem}

Bilișim sektöründe yer alan ișletme çalıșanları araștırmanın hedef kitlesini olușturmaktadır. TÜlK verilerine göre ülkemizdeki büyük ölçekli ișletmelerde 3,5 milyon kiși çalıșmaktadır. 2008 yılında TÜIKK tarafından yayınlanan raporda girișimlerin faaliyet sınıflandırılması verilmiștir. Söz konusu olan bilișim sektöründeki ișletmeler, sınıflandırmada “I- Ulaștırma, Depolama ve Haberleșme Faaliyetleri” içerisinde yer almakta ve söz konusu sınıflandırmanın toplam faaliyet alanları içerisindeki payı \%16,9'dur. Bu hesaba göre yaklașık olarak 591.000 kiși bu faaliyet alanında çalıșmaktadır.

Bu evren çerçevesinde ve basit rastlantısal örneklem türüne bağlı olarak anket soruları araștırmanın yapıldığı ișletmelerde tesadüfî olarak belirlenen 600 çalıșana uygulanmıs ve 450 anket geri dönüșü gerçekleșmiș, bu anketlerden 401'i geçerli kabul edilmiștir. Bu örneklem türünde çalıșanların birbirine kıyasla eșit seçilme durumu söz konusudur (Erdoğan, 2007: 171). Sonuç olarak araștırma bulgularının \%95 güven aralığında, $\pm \% 5$ örnekleme hatası ile genellenebileceği söylenebilmektedir (Türker, 2006: 47)

\subsection{Verilerin Analizi}

Araștırmada veri toplama araçları ile elde edilen bilgilerin çözümlenmesi SPSS 18 paket programı kullanılarak bilgisayar ortamında gerçekleștirilmiștir. Anketin güvenilirliğinin test edilmesinde Alfa Katsayısından (Cronbach Alfa) yararlanılmıștır. Yapılan analizlerde 401 katılımcıdan elde edilen veriler kullanılmıștır. Ayrıca soruların, alfa katsayısına ne derecede ve ne yönde etkide bulunduklarını saptayabilmek için; “Değișken Silindiği Takdirde Ölçeğin Alfa Katsayısı” (Alpha if Item Deleted) değeri hesaplanmıștır. Söz konusu değerler, herhangi bir değișken silindiği takdirde, geri kalan değișkenlerin iç tutarlılıklarını göstermektedir. 
Bu çerçevede ișyerinde sağlıklı beslenme ve fiziksel aktivite iklimi ölçeği anketinin güvenilirliğinin incelenmesi sonrasında $a=0,937$ gibi yüksek bir güvenilirlik değeri elde edilmiștir.

Tablo 1:

Güvenilirlik Değeri

\begin{tabular}{|c|c|}
\hline Cronbach's Alpha & Madde Sayısı \\
\hline, 937 & 23 \\
\hline
\end{tabular}

Tablo 2'de ise sübjektif sağlık șikâyetleri ölçeğinin güvenilirlik değerleri gösterilmiștir.

Tablo 2:

Sübjektif Sağlık Șikâyetleri Ölçeği Güvenilirlik Değeri

\begin{tabular}{|c|c|}
\hline Cronbach's Alpha & Madde Sayısı \\
\hline, 891 & 28 \\
\hline
\end{tabular}

Ölçeğin faktör yapısının belirlenmesinde faktör analizi yönteminden yararlanılmıștır. Varyans analizi tablosundaki verilerden ölçeğin 5 faktörden oluștuğu anlașılmaktadır. Ayrıca varyans değerleri incelendiğinde ölçeği olușturan 5 faktörün toplam varyansın \%65'ini açıkladığı görülmektedir. Sonuçlar Tablo 3'de gösterilmektedir.

Tablo 3:

Toplam Varyans

\begin{tabular}{|c|c|c|c|c|c|c|}
\hline \multirow{2}{*}{ Bileșen } & \multicolumn{3}{|c|}{ Bașlangıç Değerleri } & \multicolumn{3}{|c|}{ Yönlendirilmiş Yüklemeler Toplamı } \\
\hline & Top. & $\%$ Var. & Top. $\%$ & Top. & $\%$ Var. & Top. $\%$ \\
\hline 1 & 9,955 & 43,285 & 43,285 & 3,877 & 16,857 & 16,857 \\
\hline 2 & 1,595 & 6,936 & 50,221 & 3,509 & 15,255 & 32,112 \\
\hline 3 & 1,255 & 5,455 & 55,677 & 3,218 & 13,993 & 46,104 \\
\hline 4 & 1,171 & 5,090 & 60,767 & 3,137 & 13,640 & 59,744 \\
\hline 5 & 1,055 & 4,588 & 65,355 & 1,291 & 5,611 & 65,355 \\
\hline 6 & ,884 & 3,842 & 69,196 & & & \\
\hline 7 & ,790 & 3,436 & 72,632 & & & \\
\hline 8 & ,733 & 3,187 & 75,819 & & & \\
\hline 9 & ,634 & 2,755 & 78,574 & & & \\
\hline 10 &, 533 & 2,318 & 80,892 & & & \\
\hline 11 &, 525 & 2,284 & 83,176 & & & \\
\hline 12 & ,484 & 2,105 & 85,281 & & & \\
\hline
\end{tabular}




\begin{tabular}{|l|l|l|l|l|l|l|}
\hline $\mathbf{1 3}$ &, 437 & 1,901 & 87,182 & & & \\
\hline $\mathbf{1 4}$ &, 427 & 1,854 & 89,036 & & & \\
\hline $\mathbf{1 5}$ &, 401 & 1,742 & 90,778 & & & \\
\hline $\mathbf{1 6}$ &, 365 & 1,588 & 92,365 & & & \\
\hline $\mathbf{1 7}$ &, 338 & 1,469 & 93,834 & & & \\
\hline $\mathbf{1 8}$ &, 298 & 1,294 & 95,128 & & & \\
\hline $\mathbf{1 9}$ &, 273 & 1,186 & 96,315 & & & \\
\hline $\mathbf{2 0}$ &, 259 & 1,127 & 97,442 & & & \\
\hline $\mathbf{2 1}$ &, 226 &, 982 & 98,424 & & & \\
\hline $\mathbf{2 2}$ &, 190 &, 827 & 99,250 & & & \\
\hline $\mathbf{2 3}$ &, 172 &, 750 & 100,000 & & & \\
\hline
\end{tabular}

Tablo 4'de gösterilen temel bileșenler analizi sonrasında elde edilen bileșen matrisinde de ölçeğin 5 faktörden oluștuğu anlașılmakla birlikte, belirgin bir faktör yapısı elde edilememiștir. Bu nedenle her bir faktörün yüklemelerini daha net olarak görerek faktörler arası karșılaștırmaya imkân vermek amacıyla elde edilen 5 faktörlük sonuç yönlendirmeye tabii tutulmuștur. Bu amaçla Varimax yönlendirme metodu kullanılmıștır. Sonuçlar Tablo 4'de gösterilmektedir.

Tablo 4:

Temel Bileșenler Matrisi

\begin{tabular}{|c|c|c|c|c|c|}
\hline & \multicolumn{5}{|c|}{ Bileșen } \\
\hline & 1 & 2 & 3 & 4 & 5 \\
\hline 1. Șirketim çalıșanlarının egzersiz yapmasına önem verir. & .659 & & & & \\
\hline $\begin{array}{l}\text { 2. Șirketim çalıșanlarının sağlıklı beslenmesine önem } \\
\text { verir. }\end{array}$ & 680 & & & & \\
\hline $\begin{array}{l}\text { 3. Șirket çalıșanlarına sağlıklı besinler yeterli ölçüde } \\
\text { tanıtılmaktadır. }\end{array}$ &, 732 & & & & \\
\hline $\begin{array}{l}\text { 4. Șirket çalıșanlarına uygun egzersiz alıșkanlıkları yeterli } \\
\text { ölçüde anlatılmaktadır. }\end{array}$ & .731 & & & & \\
\hline $\begin{array}{l}\text { 5. Șirket çalıșanları sağlıklı beslenmeye büyük önem } \\
\text { vermektedirler. }\end{array}$ & .718 & & & & \\
\hline $\begin{array}{l}\text { 6. Șirket çalıșanları düzgün egzersiz yapmaya büyük önem } \\
\text { vermektedirler. }\end{array}$ &, 701 & & & & \\
\hline $\begin{array}{l}\text { 7. Șirket çalıșanları birbirlerinin egzersiz alıșkanlıklarını } \\
\text { desteklerler. }\end{array}$ & .706 & & & & \\
\hline $\begin{array}{l}\text { 8. Șirketteki çalıșanların büyük bir kısmı fiziksel olarak } \\
\text { formdadır. }\end{array}$ & 674 & & & & \\
\hline 9. Șirket çalıșanları sağlıklı beslenmeye teșvik edilirler. & ,780 & & & & \\
\hline
\end{tabular}




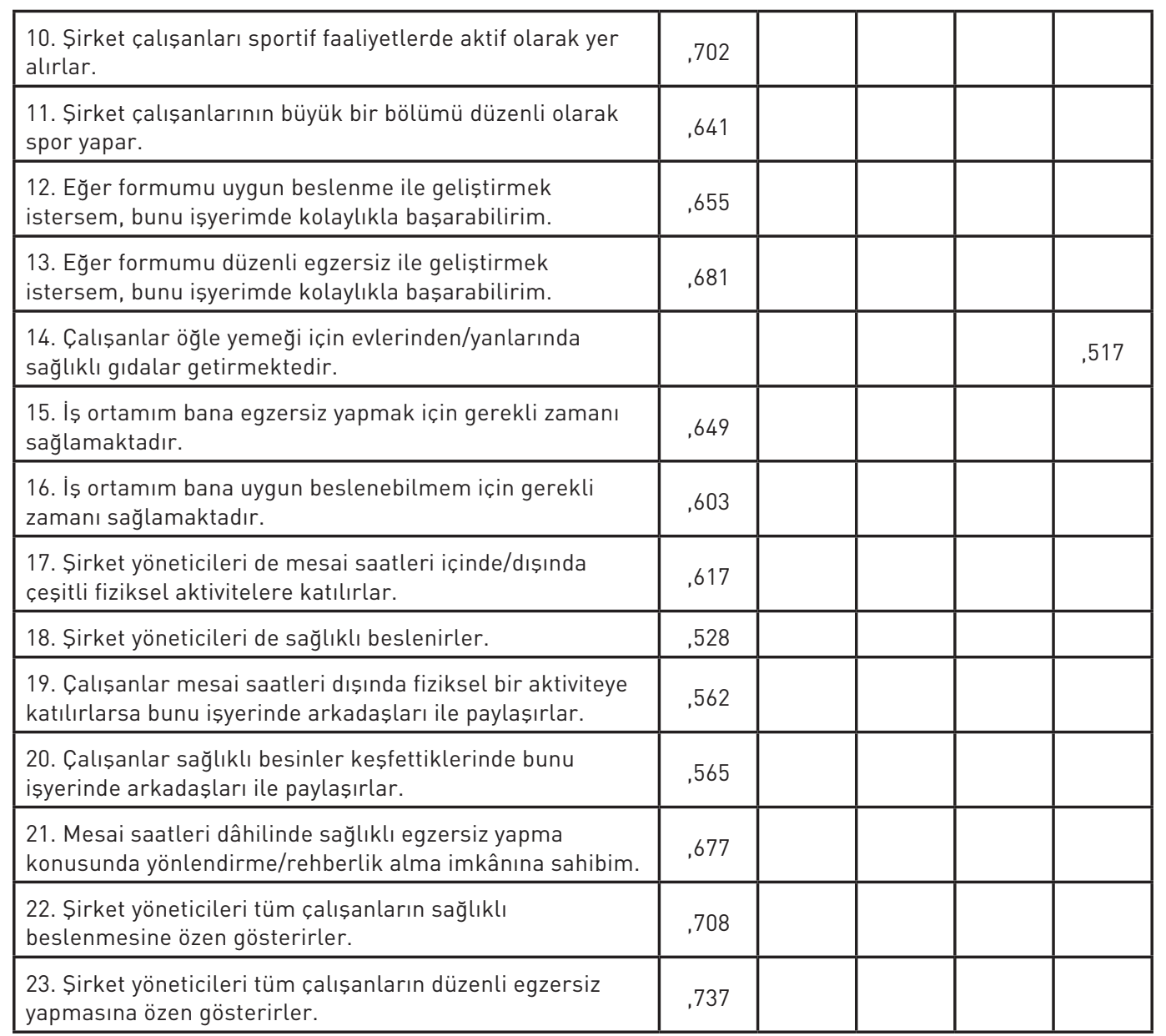

Tablo 4' de değerlerden “Çalıșanlar öğle yemeği için evlerinden/yanlarında sağlıklı gıdalar getirmektedir" maddesi ayrı bir faktör olarak yer almaktadır. Sağlıklı bir faktör yapısı için her bir faktör altında en az üç soru olması gerekliliği dikkate alınarak söz konusu madde ölçekten çıkartılmıș ve analiz tekrarlanmıștır (Stevens, 2009: 35). Tablo 5'te çıkarılan soru ile olușturulan yönlendirilmiș temel bileșenler matrisi ortaya konmuștur.

Tablo 5:

Yönlendirilmiș Temel Bileșenler Matrisi

\begin{tabular}{|l|c|c|c|c|c|}
\hline & \multicolumn{5}{|c|}{ Bileșen } \\
\hline & $\mathbf{1}$ & $\mathbf{2}$ & $\mathbf{3}$ & $\mathbf{4}$ & $\mathbf{5}$ \\
\hline 1. Șirketim çalıșanlarının egzersiz yapmasına önem verir. &, 635 & & & & \\
\hline $\begin{array}{l}\text { 2. Șirketim çalıșanlarının sağlıklı beslenmesine önem } \\
\text { verir. }\end{array}$ & & & & \multirow{5}{*}{, 582} & \\
\hline $\begin{array}{l}\text { 3. Șirket çalıșanlarına sağlıklı besinler yeterli ölçüde } \\
\text { tanıtılmaktadır. }\end{array}$ &, 543 & & &, 552 & \\
\hline
\end{tabular}




\begin{tabular}{|c|c|c|c|c|c|}
\hline $\begin{array}{l}\text { 4. Șirket çalıșanlarına uygun egzersiz alıșkanlıkları yeterli } \\
\text { ölçüde anlatılmaktadır. }\end{array}$ &, 707 & & & & \\
\hline $\begin{array}{l}\text { 5. Șirket çalıșanları sağlıklı beslenmeye büyük önem } \\
\text { vermektedirler. }\end{array}$ & & & &, 515 & \\
\hline $\begin{array}{l}\text { 6. Șirket çalıșanları düzgün egzersiz yapmaya büyük önem } \\
\text { vermektedirler. }\end{array}$ & .668 & & & & \\
\hline $\begin{array}{l}\text { 7. Șirket çalıșanları birbirlerinin egzersiz alıșkanlıklarını } \\
\text { desteklerler. }\end{array}$ & .599 & & & & \\
\hline $\begin{array}{l}\text { 8. Șirketteki çalıșanların büyük bir kısmı fiziksel olarak } \\
\text { formdadır. }\end{array}$ & & &, 561 & & \\
\hline 9. Șirket çalıșanları sağlıklı beslenmeye teșvik edilirler. & & & &, 521 & \\
\hline $\begin{array}{l}\text { 10. Sirket çalıșanları sportif faaliyetlerde aktif olarak yer } \\
\text { alırlar. }\end{array}$ & & &, 516 & & \\
\hline $\begin{array}{l}\text { 11. Sirket çalıșanlarının büyük bir bölümü düzenli olarak } \\
\text { spor yapar. }\end{array}$ & & &, 552 & & \\
\hline $\begin{array}{l}\text { 12. Eğer formumu uygun beslenme ile geliștirmek } \\
\text { istersem, bunu ișyerimde kolaylıkla bașarabilirim. }\end{array}$ & & ,708 & & & \\
\hline $\begin{array}{l}\text { 13. Eğer formumu düzenli egzersiz ile geliștirmek } \\
\text { istersem, bunu ișyerimde kolaylıkla bașarabilirim. }\end{array}$ & &, 765 & & & \\
\hline $\begin{array}{l}\text { 14. Çalıșanlar öğle yemeği için evlerinden/yanlarında } \\
\text { sağlıklı gıdalar getirmektedir. }\end{array}$ & & & & &, 811 \\
\hline $\begin{array}{l}\text { 15. İș ortamım bana egzersiz yapmak için gerekli zamanı } \\
\text { sağlamaktadır. }\end{array}$ & &, 779 & & & \\
\hline $\begin{array}{l}\text { 16. İș ortamım bana uygun beslenebilmem için gerekli } \\
\text { zamanı sağlamaktadır. }\end{array}$ & & ,654 & & & \\
\hline $\begin{array}{l}\text { 17. Sirket yöneticileri de mesai saatleri içinde/dıșında } \\
\text { çeșitli fiziksel aktivitelere katılırlar. }\end{array}$ & & & & & \\
\hline 18. Șirket yöneticileri de sağlıklı beslenirler. & & & &, 680 & \\
\hline $\begin{array}{l}\text { 19. Calıșanlar mesai saatleri dıșında fiziksel bir aktiviteye } \\
\text { katılırlarsa bunu ișyerinde arkadașları ile paylașırlar. }\end{array}$ & & & .766 & & \\
\hline $\begin{array}{l}\text { 20. Çalıșanlar sağlıklı besinler keșfettiklerinde bunu } \\
\text { ișyerinde arkadașları ile paylașırlar. }\end{array}$ & & &, 707 & & \\
\hline $\begin{array}{l}\text { 21. Mesai saatleri dâhilinde sağlıklı egzersiz yapma } \\
\text { konusunda yönlendirme/rehberlik alma imkânına sahibim. }\end{array}$ & &, 572 & & & \\
\hline $\begin{array}{l}\text { 22. Șirket yöneticileri tüm çalıșanların sağlıklı } \\
\text { beslenmesine özen gösterirler. }\end{array}$ & & & &, 753 & \\
\hline $\begin{array}{l}\text { 23. Șirket yöneticileri tüm çalıșanların düzenli egzersiz } \\
\text { yapmasına özen gösterirler. }\end{array}$ & & & &, 532 & \\
\hline
\end{tabular}

Tekrarlanan analiz sonrasında varyans analizi tablosundaki verilerden ölçeğinin 4 faktöre düștüğü anlașılmaktadır. Ayrıca varyans değerleri incelendiğinde ölçeği olușturan 4 faktörün toplam varyansın \% 64'ünü açıkladığı görülmektedir. Sonuçlar Tablo 6'da yer almaktadır. 
Tablo 6:

Toplam Varyans-2

\begin{tabular}{|c|c|c|c|c|c|c|}
\hline \multirow{2}{*}{ Bileșen } & \multicolumn{3}{|c|}{ Bașlangıç Değerleri } & \multicolumn{3}{|c|}{ Yönlendirilmiș Yüklemeler Toplamı } \\
\hline & Top. & $\%$ Var. & Top. \% & Top. & $\%$ Var. & Top. \% \\
\hline 1 & 9,565 & 45,547 & 45,547 & 3,900 & 18,570 & 18,570 \\
\hline 2 & 1,556 & 7,409 & 52,955 & 3,614 & 17,211 & 35,781 \\
\hline 3 & 1,221 & 5,815 & 58,770 & 3,546 & 16,886 & 52,667 \\
\hline 4 & 1,127 & 5,368 & 64,139 & 2,409 & 11,472 & 64,139 \\
\hline 5 & 870 & 4,144 & 68,283 & & & \\
\hline 6 & 809 & 3,851 & 72,135 & & & \\
\hline 7 &, 742 & 3,535 & 75,669 & & & \\
\hline 8 &, 558 & 2,658 & 78,327 & & & \\
\hline 9 & .544 & 2,591 & 80,918 & & & \\
\hline 10 &, 525 & 2,500 & 83,417 & & & \\
\hline 11 & ,483 & 2,298 & 85,716 & & & \\
\hline 12 &, 433 & 2,060 & 87,776 & & & \\
\hline 13 &, 406 & 1,931 & 89,707 & & & \\
\hline 14 & .366 & 1,743 & 91,450 & & & \\
\hline 15 &, 343 & 1,634 & 93,084 & & & \\
\hline 16 &, 314 & 1,497 & 94,580 & & & \\
\hline 17 & ,278 & 1,323 & 95,903 & & & \\
\hline 18 &, 265 & 1,262 & 97,165 & & & \\
\hline 19 & ,228 & 1,084 & 98,249 & & & \\
\hline 20 & ,194 &, 926 & 99,175 & & & \\
\hline 21 & ,173 & ,825 & 100,000 & & & \\
\hline 22 & 190 & 827 & 99,250 & & & \\
\hline 23 & 172 &, 750 & 100,000 & & & \\
\hline
\end{tabular}

Temel bileșenler analizi sonrasında elde edilen bileșen matrisinde de ölçeğin 4 faktörden oluștuğu anlașılmakla birlikte, belirgin bir faktör yapısı elde edilememiștir. Bu nedenle her bir faktörün yüklemelerini daha net olarak görerek faktörler arası karşılaștırmaya imkân vermek amacıyla elde edilen 4 faktörlük sonuç yönlendirmeye tabii tutulmuștur. Bu amaçla Varimax yönlendirme metodu kullanılmıștır. Sonuçlar Tablo 7'de yer almaktadır. 
Tablo 7:

Temel Bileșenler Matrisi-2

\begin{tabular}{|c|c|c|c|c|}
\hline & \multicolumn{4}{|c|}{ Bileșen } \\
\hline & 1 & 2 & 3 & 4 \\
\hline 1. Șirketim çalıșanlarının egzersiz yapmasına önem verir. & .668 & & & \\
\hline 2. Șirketim çalıșanlarının sağlıklı beslenmesine önem verir. & 691 & & & \\
\hline 3. Șirket çalıșanlarına sağlıklı besinler yeterli ölçüde tanıtılmaktadır. & .736 & & & \\
\hline $\begin{array}{l}\text { 4. Șirket çalıșanlarına uygun egzersiz alıșkanlıkları yeterli ölçüde } \\
\text { anlatılmaktadır. }\end{array}$ & ,732 & & & \\
\hline 5. Șirket çalıșanları sağlıklı beslenmeye büyük önem vermektedirler. &, 721 & & & \\
\hline $\begin{array}{l}\text { 6. Șirket çalıșanları düzgün egzersiz yapmaya büyük önem } \\
\text { vermektedirler. }\end{array}$ & .704 & & & \\
\hline $\begin{array}{l}\text { 7. Șirket çalıșanları birbirlerinin egzersiz alıșkanlıklarını } \\
\text { desteklerler. }\end{array}$ & .709 & & & \\
\hline 8. Șirketteki çalıșanların büyük bir kısmı fiziksel olarak formdadır. & 671 & & & \\
\hline 9. Șirket çalıșanları sağlıklı beslenmeye teșvik edilirler. & .785 & & & \\
\hline 10. Șirket çalıșanları sportif faaliyetlerde aktif olarak yer alırlar. & .699 & & & \\
\hline 11. Șirket çalıșanlarının büyük bir bölümü düzenli olarak spor yapar. & 637 & & & \\
\hline $\begin{array}{l}\text { 12. Eğer formumu uygun beslenme ile geliștirmek istersem, bunu } \\
\text { ișyerimde kolaylıkla bașarabilirim. }\end{array}$ & 657 & & & \\
\hline $\begin{array}{l}\text { 13. Eğer formumu düzenli egzersiz ile geliștirmek istersem, bunu } \\
\text { ișyerimde kolaylıkla bașarabilirim. }\end{array}$ & .686 & & & \\
\hline $\begin{array}{l}\text { 15. İș ortamım bana egzersiz yapmak için gerekli zamanı } \\
\text { sağlamaktadır. }\end{array}$ & .647 & & & \\
\hline $\begin{array}{l}\text { 16. İs ortamım bana uygun beslenebilmem için gerekli zamanı } \\
\text { sağlamaktadır. }\end{array}$ & 605 & & & \\
\hline 18. Șirket yöneticileri de sağlıklı beslenirler. &, 518 & & & \\
\hline $\begin{array}{l}\text { 19. Çalıșanlar mesai saatleri dıșında fiziksel bir aktiviteye } \\
\text { katılırlarsa bunu ișyerinde arkadașları ile paylașırlar. }\end{array}$ & .557 & & & \\
\hline $\begin{array}{l}\text { 20. Çalıșanlar sağlıklı besinler keșfettiklerinde bunu ișyerinde } \\
\text { arkadașları ile paylașırlar. }\end{array}$ & .566 & & & \\
\hline $\begin{array}{l}\text { 21. Mesai saatleri dâhilinde sağlıklı egzersiz yapma konusunda } \\
\text { yönlendirme/rehberlik alma imkânına sahibim. }\end{array}$ & .677 & & & \\
\hline $\begin{array}{l}\text { 22. Șirket yöneticileri tüm çalıșanların sağlıklı beslenmesine özen } \\
\text { gösterirler. }\end{array}$ & ,709 & & & \\
\hline $\begin{array}{l}\text { 23. Şrket yöneticileri tüm çalışanların düzenli egzersiz yapmasına } \\
\text { özen gösterirler. }\end{array}$ & .734 & & & \\
\hline
\end{tabular}

Varimax yöntemi kullanılarak yapılan yönlendirme sonucunda elde edilen faktör yapısı Tablo 8'de sunulmuștur. Tablodaki değerlerden “Çalıșanlar mesai saatleri dıșında fiziksel bir aktiviteye katılırlarsa bunu ișyerinde arkadașları ile paylașırlar", "CCalıșanlar 
sağlıklı besinler keșfettiklerinde bunu ișyerinde arkadaşları ile paylaşırlar" maddeleri ayrı bir faktör olarak yer almaktadır. Sağlıklı bir faktör yapısı için her bir faktör altında en az üç soru olması gerekliliği dikkate alınarak söz konusu madde ölçekten çıkartılmıs ve analiz tekrarlanmıștır (Stevens, 2009: 40).

Tablo 8:

Yönlendirilmiș Temel Bileșenler Matrisi-2

\begin{tabular}{|c|c|c|c|c|}
\hline & \multicolumn{4}{|c|}{ Bileșen } \\
\hline & 1 & 2 & 3 & 4 \\
\hline 1. Șirketim çalıșanlarının egzersiz yapmasına önem verir. & & &, 536 & \\
\hline 2. Șirketim çalıșanlarının sağlıklı beslenmesine önem verir. & & .662 & & \\
\hline 3. Șirket çalıșanlarına sağlıklı besinler yeterli ölçüde tanıtılmaktadır. & & .644 & & \\
\hline $\begin{array}{l}\text { 4. Șirket çalıșanlarına uygun egzersiz alıșkanlıkları yeterli ölçüde } \\
\text { anlatılmaktadır. }\end{array}$ & 651 & & & \\
\hline 5. Șirket çalıșanları sağlıklı beslenmeye büyük önem vermektedirler. & & .566 & & \\
\hline $\begin{array}{l}\text { 6. Șirket çalıșanları düzgün egzersiz yapmaya büyük önem } \\
\text { vermektedirler. }\end{array}$ & .741 & & & \\
\hline $\begin{array}{l}\text { 7. Șirket çalıșanları birbirlerinin egzersiz alıșkanlıklarını } \\
\text { desteklerler. }\end{array}$ & 682 & & & \\
\hline 8. Șirketteki çalıșanların büyük bir kısmı fiziksel olarak formdadır. & .540 & & & \\
\hline 9. Şirket çalışanları sağlıklı beslenmeye teșvik edilirler. & & .587 & & \\
\hline 10. Sirket çalıșanları sportif faaliyetlerde aktif olarak yer alırlar. & 609 & & & \\
\hline 11. Șirket çalıșanlarının büyük bir bölümü düzenli olarak spor yapar. &, 551 & & & \\
\hline $\begin{array}{l}\text { 12. Eğer formumu uygun beslenme ile geliștirmek istersem, bunu } \\
\text { ișyerimde kolaylıkla bașarabilirim. }\end{array}$ & & &, 710 & \\
\hline $\begin{array}{l}\text { 13. Eğer formumu düzenli egzersiz ile geliștirmek istersem, bunu } \\
\text { ișyerimde kolaylıkla bașarabilirim. }\end{array}$ & & & ,785 & \\
\hline $\begin{array}{l}\text { 15. İș ortamım bana egzersiz yapmak için gerekli zamanı } \\
\text { sağlamaktadır. }\end{array}$ & & & ,780 & \\
\hline $\begin{array}{l}\text { 16. İs ortamım bana uygun beslenebilmem için gerekli zamanı } \\
\text { sağlamaktadır. }\end{array}$ & & & ,642 & \\
\hline 18. Șirket yöneticileri de sağlıklı beslenirler. & & 623 & & \\
\hline $\begin{array}{l}\text { 19. Çalıșanlar mesai saatleri dıșında fiziksel bir aktiviteye } \\
\text { katılırlarsa bunu ișyerinde arkadașları ile paylaşırlar. }\end{array}$ & & & & .765 \\
\hline $\begin{array}{l}\text { 20. Calıșanlar sağlıklı besinler keșfettiklerinde bunu ișyerinde } \\
\text { arkadașları ile paylașırlar. }\end{array}$ & & & & 693 \\
\hline $\begin{array}{l}\text { 21. Mesai saatleri dâhilinde sağlıklı egzersiz yapma konusunda } \\
\text { yönlendirme/rehberlik alma imkânına sahibim. }\end{array}$ & & & ,582 & \\
\hline $\begin{array}{l}\text { 22. Șirket yöneticileri tüm çalıșanların sağlıklı beslenmesine özen } \\
\text { gösterirler. }\end{array}$ & & ,771 & & \\
\hline $\begin{array}{l}\text { 23. Sirket yöneticileri tüm çalıșanların düzenli egzersiz yapmasına } \\
\text { özen gösterirler. }\end{array}$ & &, 571 & & \\
\hline
\end{tabular}


Tekrarlanan analiz sonrasında Varyans Analizi tablosundaki verilerden ölçeğinin faktör sayısının değișmediği anlașılmaktadır. Ayrıca varyans değerleri incelendiğinde ölçeği olușturan 4 faktörün toplam varyansın \%66'sını açıkladığı görülmektedir. Dolayısıyla anketten 2 sorunun çıkartılması ölçeğin açıklama gücünü \%2 oranında arttırmıștır. Sonuçlar Tablo 9'da yer almaktadır.

Tablo 9:

Toplam Varyans-3

\begin{tabular}{|c|c|c|c|c|c|c|}
\hline \multirow{2}{*}{ Bilesen } & \multicolumn{3}{|c|}{ Bașlangıç Değerleri } & \multicolumn{3}{|c|}{ Yönlendirilmiș Yüklemeler Toplamı } \\
\hline & Top. & $\%$ Var. & Top. $\%$ & Top. & $\%$ Var. & Top. $\%$ \\
\hline 1 & 9,005 & 47,397 & 47,397 & 3,397 & 17,876 & 17,876 \\
\hline 2 & 1,447 & 7,617 & 55,014 & 3,216 & 16,924 & 34,800 \\
\hline 3 & 1,132 & 5,960 & 60,974 & 3,133 & 16,491 & 51,291 \\
\hline 4 & 1,025 & 5,394 & 66,369 & 2,865 & 15,077 & 66,369 \\
\hline 5 & ,820 & 4,317 & 70,686 & & & \\
\hline 6 & ,768 & 4,044 & 74,730 & & & \\
\hline 7 &, 560 & 2,949 & 77,678 & & & \\
\hline 8 &, 528 & 2,777 & 80,455 & & & \\
\hline 9 & .516 & 2,713 & 83,169 & & & \\
\hline 10 & ,487 & 2,561 & 85,730 & & & \\
\hline 11 & ,420 & 2,211 & 87,941 & & & \\
\hline 12 & ,398 & 2,094 & 90,035 & & & \\
\hline 13 & .361 & 1,900 & 91,934 & & & \\
\hline 14 & ,340 & 1,788 & 93,723 & & & \\
\hline 15 & .314 & 1,651 & 95,374 & & & \\
\hline 16 &, 266 & 1,401 & 96,774 & & & \\
\hline 17 & 237 & 1,247 & 98,022 & & & \\
\hline 18 & ,201 & 1,060 & 99,081 & & & \\
\hline 19 & , 175 &, 919 & 100,000 & & & \\
\hline
\end{tabular}

Temel bileșenler analizi sonrasında elde edilen bileșen matrisinde de ölçeğin 4 faktörden oluștuğu anlașılmakla birlikte, belirgin bir faktör yapısı elde edilememiștir. Bu nedenle her bir faktörün yüklemelerini daha net olarak görerek faktörler arası karșılaștırmaya imkân vermek amacıyla elde edilen 4 faktörlük sonuç yönlendirmeye tabii tutulmuștur. Bu amaçla Varimax yönlendirme metodu kullanılmıștır. Sonuçlar Tablo 10 'da yer almaktadır. 
Tablo 10:

Temel Bileșenler Matrisi-3

\begin{tabular}{|c|c|c|c|c|}
\hline & \multicolumn{4}{|c|}{ Bileșen } \\
\hline & 1 & 2 & 3 & 4 \\
\hline 1. Șirketim çalıșanlarının egzersiz yapmasına önem verir. & 680 & & & \\
\hline 2. Șirketim çalıșanlarının sağlıklı beslenmesine önem verir. &, 700 & & & \\
\hline 3. Șirket çalıșanlarına sağlıklı besinler yeterli ölçüde tanıtılmaktadır. &, 743 & & & \\
\hline $\begin{array}{l}\text { 4. Șirket çalıșanlarına uygun egzersiz alıșkanlıkları yeterli ölçüde } \\
\text { anlatılmaktadır. }\end{array}$ &, 747 & & & \\
\hline 5. Șirket çalıșanları sağlıklı beslenmeye büyük önem vermektedirler. &, 718 & & & \\
\hline $\begin{array}{l}\text { 6. Șirket çalıșanları düzgün egzersiz yapmaya büyük önem } \\
\text { vermektedirler. }\end{array}$ & ,704 & & & \\
\hline $\begin{array}{l}\text { 7. Șirket çalıșanları birbirlerinin egzersiz alıșkanlıklarını } \\
\text { desteklerler. }\end{array}$ & ,700 & & & \\
\hline 8. Şirketteki çalıșanların büyük bir kısmı fiziksel olarak formdadır. & .662 & & & \\
\hline 9. Șirket çalıșanları sağlıklı beslenmeye teșvik edilirler. &, 786 & & & \\
\hline 10. Șirket çalıșanları sportif faaliyetlerde aktif olarak yer alırlar. & 695 & & & \\
\hline 11. Șirket çalıșanlarının büyük bir bölümü düzenli olarak spor yapar. & 633 & & & \\
\hline $\begin{array}{l}\text { 12. Eğer formumu uygun beslenme ile geliștirmek istersem, bunu } \\
\text { ișyerimde kolaylıkla bașarabilirim. }\end{array}$ & ,656 & & & \\
\hline $\begin{array}{l}\text { 13. Eğer formumu düzenli egzersiz ile geliștirmek istersem, bunu } \\
\text { ișyerimde kolaylıkla bașarabilirim. }\end{array}$ & 699 & & & \\
\hline $\begin{array}{l}\text { 15. İș ortamım bana egzersiz yapmak için gerekli zamanı } \\
\text { sağlamaktadır. }\end{array}$ & 657 &, 518 & & \\
\hline $\begin{array}{l}\text { 16. İș ortamım bana uygun beslenebilmem için gerekli zamanı } \\
\text { sağlamaktadır. }\end{array}$ & .604 & & & \\
\hline 18. Șirket yöneticileri de sağlıklı beslenirler. &, 510 & &, 535 & \\
\hline $\begin{array}{l}\text { 21. Mesai saatleri dâhilinde sağlıklı egzersiz yapma konusunda } \\
\text { yönlendirme/rehberlik alma imkânına sahibim. }\end{array}$ & 687 & & & \\
\hline $\begin{array}{l}\text { 22. Șirket yöneticileri tüm çalıșanların sağlıklı beslenmesine özen } \\
\text { gösterirler. }\end{array}$ &, 713 & & & \\
\hline $\begin{array}{l}\text { 23. Șirket yöneticileri tüm çalıșanların düzenli egzersiz yapmasına } \\
\text { özen gösterirler. }\end{array}$ &, 742 & & & \\
\hline
\end{tabular}

Varimax yöntemi kullanılarak yapılan yönlendirme sonucunda elde edilen faktör yapısı aşağıda sunulmuștur:

\section{İșletmenin Egzersize Verdiği Önem ve Yönlendirme}

1. Șirketim çalıșanlarının egzersiz yapmasına önem verir.

4. Şirket çalıșanlarına uygun egzersiz alıșkanlıkları yeterli ölçüde anlatılmaktadır.

21. Mesai saatleri dâhilinde sağlıklı egzersiz yapma konusunda yönlendirme/rehberlik 
alma imkânına sahibim.

23. Șirket yöneticileri tüm çalıșanların düzenli egzersiz yapmasına özen gösterirler.

\section{İșletmenin Sağlıklı Beslenmeye Verdiği Önem ve Yönlendirme}

2. Șirketim çalıșanlarının sağlıklı beslenmesine önem verir.

3. Sirket çalıșanlarına sağlıklı besinler yeterli ölçüde tanıtılmaktadır.

5. Şirket çalıșanları sağlıklı beslenmeye büyük önem vermektedirler.

9. Șirket çalıșanları sağlıklı beslenmeye teșvik edilirler.

18. Sirket yöneticileri de sağlıklı beslenirler.

22. Șirket yöneticileri tüm çalıșanların sağlıklı beslenmesine özen gösterirler.

\section{İșletme Calıșanlarının Egzersize Verdikleri Önem}

6. Sirket çalıșanları düzgün egzersiz yapmaya büyük önem vermektedirler.

7. Șirket çalıșanları birbirlerinin egzersiz alıșkanlıklarını desteklerler.

8. Șirketteki çalıșanların büyük bir kısmı fiziksel olarak formdadır.

10. Sirket çalıșanları sportif faaliyetlerde aktif olarak yer alırlar.

11. Șirket çalıșanlarının büyük bir bölümü düzenli olarak spor yapar.

\section{İşyeri Ortamının Sağlıklı Beslenme ve Egzersiz İçin Uygunluğu}

12. Eğer formumu uygun beslenme ile geliștirmek istersem, bunu ișyerimde kolaylıkla bașarabilirim.

13. Eğer formumu düzenli egzersiz ile geliștirmek istersem, bunu ișyerimde kolaylıkla bașarabilirim.

15. İs ortamım bana egzersiz yapmak için gerekli zamanı sağlamaktadır.

16. İs ortamım bana uygun beslenebilmem için gerekli zamanı sağlamaktadır.

Bundan sonra yapılan analizlerde faktör bazında ortalamalar alınmıș ve her bir faktörün çalıșan sağlığına etkisi araștırılmıștır. Sonuçlar Tablo 11'de yer almaktadır.

Tablo 11:

Yönlendirilmiș Temel Bileșenler Matrisi

\begin{tabular}{|l|c|c|c|c|}
\hline & \multicolumn{3}{|c|}{ Bilesen } \\
\hline & $\mathbf{1}$ & $\mathbf{2}$ & $\mathbf{3}$ & $\mathbf{4}$ \\
\hline 1. Şirketim çalıșanlarının egzersiz yapmasına önem verir. & &, 703 & & \\
\hline 2. Şirketim çalıșanlarının sağlıkıı beslenmesine önem verir. & & &, 613 & \\
\hline 3. Şirket çalıșanlarına sağlıkı besinler yeterli ölçüde tanıtılmaktadır. & &, 504 &, 567 & \\
\hline $\begin{array}{l}\text { 4. Sirket çalıșanlarına uygun egzersiz alıșkanlıkları yeterli ölçüde } \\
\text { anlatımaktadır. }\end{array}$ & &, 741 & & \\
\hline 5. Sirket çalıșanları sağlıklı beslenmeye büyük önem vermektedirler. & & &, 563 & \\
\hline
\end{tabular}




\begin{tabular}{|c|c|c|c|c|}
\hline $\begin{array}{l}\text { 6. Șirket çalıșanları düzgün egzersiz yapmaya büyük önem } \\
\text { vermektedirler. }\end{array}$ & .658 & & & \\
\hline $\begin{array}{l}\text { 7. Șirket çalıșanları birbirlerinin egzersiz alıșkanlıklarını } \\
\text { desteklerler. }\end{array}$ &, 628 & & & \\
\hline 8. Șirketteki çalıșanların büyük bir kısmı fiziksel olarak formdadır. & .710 & & & \\
\hline 9. Șirket çalıșanları sağlıklı beslenmeye teșvik edilirler. & & &, 551 & \\
\hline 10. Șirket çalıșanları sportif faaliyetlerde aktif olarak yer alırlar. & .697 & & & \\
\hline 11. Șirket çalıșanlarının büyük bir bölümü düzenli olarak spor yapar. & .755 & & & \\
\hline $\begin{array}{l}\text { 12. Eğer formumu uygun beslenme ile geliștirmek istersem, bunu } \\
\text { ișyerimde kolaylıkla bașarabilirim. }\end{array}$ & & & & ,773 \\
\hline $\begin{array}{l}\text { 13. Eğer formumu düzenli egzersiz ile geliștirmek istersem, bunu } \\
\text { ișyerimde kolaylıkla bașarabilirim. }\end{array}$ & & & & ,737 \\
\hline $\begin{array}{l}\text { 15. İș ortamım bana egzersiz yapmak için gerekli zamanı } \\
\text { sağlamaktadır. }\end{array}$ & & & & .678 \\
\hline $\begin{array}{l}\text { 16. İș ortamım bana uygun beslenebilmem için gerekli zamanı } \\
\text { sağlamaktadır. }\end{array}$ & & & &, 709 \\
\hline 18. Șirket yöneticileri de sağlıklı beslenirler. & & & ,705 & \\
\hline $\begin{array}{l}\text { 21. Mesai saatleri dâhilinde sağlıklı egzersiz yapma konusunda yön- } \\
\text { lendirme/rehberlik alma imkânına sahibim. }\end{array}$ & & .566 & & \\
\hline $\begin{array}{l}\text { 22. Șirket yöneticileri tüm çalıșanların sağlıklı beslenmesine özen } \\
\text { gösterirler. }\end{array}$ & & & ,735 & \\
\hline $\begin{array}{l}\text { 23. Şirket yöneticileri tüm çalıșanların düzenli egzersiz yapmasına } \\
\text { özen gösterirler. }\end{array}$ & &, 534 & & \\
\hline
\end{tabular}

\section{Bulgular ve Yorum}

Bulgular yorumlanırken İș Ortamının Sağlıklı Beslenme ve Egzersiz İçin Uygunluğu”, “Şirketin Egzersize Verdiği Önem ve Yönlendirme”, “Şirketin Sağlıklı Beslenmeye Verdiği Önem ve Yönlendirme”, “Şirket Çalıșanların Egzersize Verdikleri Önem” bașlıkları altında incelenmiș ve her bir boyutun çalıșanların sağlığı üzerindeki görece etkisi karşılaștırmalı olarak sorgulanmıștır. Ayrıca araștırmanın örneklemine ilișkin demografik bilgiler tanımlayıcı istatistikler yardımıyla özetlenmiștir.

Örneklem grubunun demografik özelliklerine göre dağılımı frekans ve yüzde tanımlayıcı istatistikleri kullanarak incelenmiștir. Örneklem grubunun cinsiyetlerine göre dağılımları \%42 erkek, \%58 kadındır. Katılımcıların \%48'i evli, \%52'si bekârdır. Katılımcıların \%50'si 30 yașın altında iken, \%37'si 31-40 yaș arası, \%9'u 41-50 yaș arası, \%4'ü 51-60 yaș arasındadır. Araștırmanın ana hipotezleri sorgulanırken SB ve FA ile çalıșanların sağlık durumu arasındaki ilișki değerlendirilmiștir. 
Tablo 12:

FA ve SB ile Sağlık Durumu Arasındaki İlișki

\begin{tabular}{|c|c|c|c|c|c|c|}
\hline & & $\begin{array}{l}\text { Sağlık } \\
\text { Durumu }\end{array}$ & $\begin{array}{l}\text { İșletmenin } \\
\text { Egzersize } \\
\text { Verdiği } \\
\text { Önem ve } \\
\text { Yönlendirm }\end{array}$ & $\begin{array}{l}\text { İșletmenin } \\
\text { Sağlıklı } \\
\text { Beslenmeye } \\
\text { Verdiği } \\
\text { Önem ve } \\
\text { Yönlendirm }\end{array}$ & $\begin{array}{l}\text { İșletme } \\
\text { Çalıșanların } \\
\text { Egzersize } \\
\text { Verdikleri } \\
\text { Önem }\end{array}$ & $\begin{array}{l}\text { İș Ortamının } \\
\text { Sağlıklı } \\
\text { Beslenme ve } \\
\text { Egzersiz İçin } \\
\text { Uygunluğu }\end{array}$ \\
\hline \multirow{3}{*}{$\begin{array}{l}\text { Sağlık } \\
\text { Durumu }\end{array}$} & $\begin{array}{c}\text { Pearson } \\
\text { Korelasyonu }\end{array}$ & 1 &,$- 224^{* *}$ &,$- 250 * *$ &,$- 170^{* *}$ &,$- 272^{* *}$ \\
\hline & Anlamlılık & & ,000 & ,000 & ,001 & ,000 \\
\hline & $\mathrm{N}$ & 401 & 401 & 401 & 401 & 401 \\
\hline \multirow{3}{*}{$\begin{array}{l}\text { İșletmenin } \\
\text { Egzersize } \\
\text { Verdiği } \\
\text { Önem ve } \\
\text { Yönlendirme }\end{array}$} & $\begin{array}{c}\text { Pearson } \\
\text { Korelasyonu }\end{array}$ &,$- 224^{* *}$ & 1 &, $714^{* *}$ &, $678 * *$ &, $677^{* *}$ \\
\hline & Anlamlılık & ,000 & & ,000 & ,000 & ,000 \\
\hline & $\mathrm{N}$ & 401 & 401 & 401 & 401 & 401 \\
\hline \multirow{3}{*}{$\begin{array}{l}\text { İșletmenin } \\
\text { Sağlıklı } \\
\text { Beslenmeye } \\
\text { Verdiği } \\
\text { Önem ve } \\
\text { Yönlendirme }\end{array}$} & $\begin{array}{c}\text { Pearson } \\
\text { Korelasyonu }\end{array}$ &,$- 250 * *$ &, $714^{* *}$ & 1 &, $692 * *$ & ,610** \\
\hline & Anlamlılık & ,000 &, 000 & &, 000 &, 000 \\
\hline & $\mathrm{N}$ & 401 & 401 & 401 & 401 & 401 \\
\hline \multirow{3}{*}{$\begin{array}{l}\text { İșletme } \\
\text { Çalışanların } \\
\text { Egzersize } \\
\text { Verdikleri } \\
\text { Önem }\end{array}$} & $\begin{array}{c}\text { Pearson } \\
\text { Korelasyonu }\end{array}$ &,$- 170 * *$ &, $678 * *$ &, $692 * *$ & 1 &, $554^{* *}$ \\
\hline & Anlamlılık & ,001 &, 000 &, 000 & &, 000 \\
\hline & $\mathrm{N}$ & 401 & 401 & 401 & 401 & 401 \\
\hline \multirow{3}{*}{$\begin{array}{c}\text { İșyeri } \\
\text { Ortamının } \\
\text { Sağlıklı } \\
\text { Beslenme ve } \\
\text { Egzersiz İçin } \\
\text { Uygunluğu }\end{array}$} & $\begin{array}{c}\text { Pearson } \\
\text { Korelasyonu }\end{array}$ &,$- 272 * *$ &, $677 * *$ &, $610 * *$ &, $554^{* *}$ & 1 \\
\hline & Anlamlılık &, 000 &, 000 &, 000 &, 000 & \\
\hline & $N$ & 401 & 401 & 401 & 401 & 401 \\
\hline
\end{tabular}

Tablo 12'deki değerler, katılımcıların “İşyeri Ortamının Sağlıklı Beslenme ve Egzersiz İçin Uygunluğu”, “İșletmenin Egzersize Verdiği Önem ve Yönlendirme”, “İşletmenin Sağlıklı Beslenmeye Verdiği Önem ve Yönlendirme”, “ișletme Çalıșanlarının Egzersize Verdikleri Önem” faktörlerinden aldıkları puanlar ile “Sübjektif Sağlık Șikâyetleri” ölçeğinden aldıkları değerler arasında $\mathrm{p} \leftarrow, 0.01$ düzeyinde negatif bir ilișki olduğunu ortaya koymaktadır. Bu bulgudan hareketle ișyerindeki fiziksel aktivite ve sağlıklı beslenme hizmetlerinin niteliği yükseldikçe, çalıșanların sağlık șikâyetlerinin azaldığı söylenebilir. Bununla birlikte korelasyon analizi birden fazla bağımsız değișkenin tek bir bağımlı değișken üzerindeki bütünleșik etkisini göstermede sınırlılıkları olan bir analiz yöntemidir. Bu nedenle daha sağlıklı bir yorum yapabilmek için basamaklı (stepwise) çoklu 
regresyon analizi kullanılmıștır. Bu yöntemde tüm değișkenler bir arada denkleme sokulmakla birlikte, bağımlı değișken üzerinde anlamlı etkiye sahip olmayan değișkenler analiz dıșı bırakılmaktadır.

Bu çerçevede hesaplanan çoklu regresyon analizi sonuçları Tablo 13'de özetlenmiștir. Buna göre “İșyeri Ortamının Sağlıklı Beslenme ve Egzersiz İçin Uygunluğu” ve “İșletmenin Sağlıklı Beslenmeye Verdiği Önem ve Yönlendirme” faktörleri bağımlı değișken olan sağlık durumu üzerinde anlamlı etkiye sahiptir.

Tablo 13:

FA ve SB ile Sağlık Durumu Arasındaki İlișkiye Ait Çoklu Regresyon Analizi Sonuçları

\begin{tabular}{|c|c|c|c|c|c|c|}
\hline \multirow{2}{*}{\multicolumn{2}{|c|}{ Model }} & \multicolumn{2}{|c|}{ Standart Olmayan Katsayılar } & \multirow{3}{*}{$\begin{array}{c}\text { Standart } \\
\text { Katsayılar } \\
\text { Beta }\end{array}$} & \multirow[t]{2}{*}{$\mathrm{t}$} & \multirow[t]{2}{*}{ Anlamlılık } \\
\hline & & $\mathrm{B}$ & Std. Hata & & & \\
\hline \multirow[b]{2}{*}{1} & (Sabit) & 458,910 & 35,260 & & 13,015 &, 000 \\
\hline & $\begin{array}{l}\text { İşyeri } \\
\text { Ortamının } \\
\text { Sağlıklı } \\
\text { Beslenme ve } \\
\text { Egzersiz İçin } \\
\text { Uygunluğu }\end{array}$ & $-74,609$ & 13,227 &,- 272 & $-5,641$ &, 000 \\
\hline \multirow{3}{*}{2} & (Sabit) & 510,982 & 42,284 & & 12,085 &, 000 \\
\hline & $\begin{array}{l}\text { İșyeri } \\
\text { Ortamının } \\
\text { Sağlıklı } \\
\text { Beslenme ve } \\
\text { Egzersiz İçin } \\
\text { Uygunluğu } \\
\end{array}$ & $-52,255$ & 16,609 &,- 190 & $-3,146$ &, 002 \\
\hline & $\begin{array}{l}\text { İșletmenin } \\
\text { Sağlıklı } \\
\text { Beslenmeye } \\
\text { Verdiği } \\
\text { Önem ve } \\
\text { Yönlendirme }\end{array}$ & $-43,603$ & 19,756 &,- 134 & $-2,207$ & ,028 \\
\hline
\end{tabular}

Tablo 14'de verilen Model Özetindeki değerler ise “isşyeri Ortamının Sağlıklı Beslenme ve Egzersiz İçin Uygunluğu” faktörünün r2 = ,074 oranında değișim yaratırken, “İșletmenin Sağlıklı Beslenmeye Verdiği Önem ve Yönlendirme" faktörü bunun üzerine $r 2=, 011$ derecesinde ek bir varyans açıklamaktadır. 
Tablo 14:

Model Özeti

\begin{tabular}{|c|c|c|c|c|c|c|}
\hline \multirow[b]{2}{*}{$\mathbf{R}$} & \multirow[b]{2}{*}{ R2 } & \multirow[b]{2}{*}{$\begin{array}{c}\text { Düzeltilmiş } \\
\text { R2 }\end{array}$} & \multirow[b]{2}{*}{ Std. Hata } & \multicolumn{3}{|c|}{ Değișim İstatistikleri } \\
\hline & & & & $\begin{array}{l}\text { R Kare } \\
\text { Değișimi }\end{array}$ & F Değiși & $\begin{array}{c}\text { F } \\
\text { Değișiminin } \\
\text { Anlamlılığı }\end{array}$ \\
\hline, 272 & 074 & ,072 & 278,96969 & ,074 & 31,817 &, 000 \\
\hline ,292 &, 085 & ,080 & 277,62608 & 011 & 4,871 & ,028 \\
\hline
\end{tabular}

Tablo 15'de veriler ise "İșletmenin Egzersize Verdiği Önem ve Yönlendirme" ve "İșletme Çalışanların Egzersize Verdikleri Önem” faktörlerinin “İşyeri Ortamının Sağlıklı Beslenme ve Egzersiz İçin Uygunluğu” ve “İșletmenin Sağlıklı Beslenmeye Verdiği Önem ve Yönlendirme" faktörleri ile birlikte alındıklarında anlamlılıklarını yitirdiklerini göstermektedir. Tabloda bağımsız değișkenler iki gruba ayrılmıș ve bunların bağımlı değișken olan “sağlık durumuna" olan etkileri ortaya konmuștur.

Tablo 15:

Analiz Dıșı Bırakılan Değișkenler

\begin{tabular}{|c|c|c|c|c|c|c|}
\hline \multicolumn{2}{|r|}{ Model } & Beta & $t$ & Anlamlılık & $\begin{array}{c}\text { Kısmi } \\
\text { Korelasyon }\end{array}$ & Tolerans \\
\hline \multirow{3}{*}{1} & $\begin{array}{l}\text { İșletmenin } \\
\text { Egzersize } \\
\text { Verdiği Önem ve } \\
\text { Yönlendirme }\end{array}$ &,- 074 & $-1,138$ & ,256 &,- 057 &, 542 \\
\hline & $\begin{array}{l}\text { İșletmenin Sağlıklı } \\
\text { Beslenmeye } \\
\text { Verdiği Önem ve } \\
\text { Yönlendirme }\end{array}$ &,- 134 & $-2,207$ & ,028 &,- 110 & ,628 \\
\hline & $\begin{array}{c}\text { İșletme } \\
\text { Çalışanlarının } \\
\text { Egzersize } \\
\text { Verdikleri Önem }\end{array}$ &,- 028 &,- 489 & .625 &,- 025 & ,693 \\
\hline \multirow{2}{*}{2} & $\begin{array}{l}\text { İșletmenin } \\
\text { Egzersize } \\
\text { Verdiği Önem ve } \\
\text { Yönlendirme }\end{array}$ & ,000 &,- 002 & , 998 & ,000 & ,397 \\
\hline & $\begin{array}{c}\text { İșletme } \\
\text { Çalıșanlarının } \\
\text { Egzersize } \\
\text { Verdikleri Önem }\end{array}$ & ,056 & 819 &, 413 & ,041 & ,494 \\
\hline
\end{tabular}

Bu bulgulardan hareketle FA ve SB hizmetlerinin niteliği ile çalıșanların sağlık durumu arasında doğrusal bir ilișki olduğu, sağlık hizmetlerinin niteliği arttıkça çalıșanların sağlık durumun olumlu yönde geliștiği sonucuna varılmıștır. Ayrıca “İșyeri Ortamının Sağlıklı Beslenme ve Egzersiz İçin Uygunluğu” ve “İsletmenin Sağlıklı Beslenmeye Verdiği 
Önem ve Yönlendirme” çalıșan sağlığını doğrudan etkileyen faktörlerdir. “Ișletmenin Egzersize Verdiği Önem ve Yönlendirme” ve “issletme Çalıșanların Egzersize Verdikleri Önem” faktörleri ise yalnız bașlarına alındıklarında çalıșan sağlığını olumlu etkilemekle birlikte, analize diğer faktörler dâhil edildiğinde anlamlılıklarını yitirmektedirler.

Bu durum ișletmenin egzersize verdiği önemin zaten kendisini iș ortamındaki değișikliklerle göstereceği, iș ortamında değișiklik olmaması durumunda söz konusu önemin anlamını yitireceği ve bu nedenlerle “İșletmenin Egzersize Verdiği Önem ve Yönlendirme" faktörünün “İşyeri Ortamının Sağlıklı Beslenme ve Egzersiz İçin Uygunluğu” faktörünün varlığında çalıșanların sağlığına anlamlı bir katkı sağlamayacağı söylenebilir.

“İșletme Çalıșanlarının Egzersize Verdikleri Önem” faktörünün ise “İşyeri Ortamının Sağlıklı Beslenme ve Egzersiz İçin Uygunluğu” ve “issletmenin Sağlıklı Beslenmeye Verdiği Önem ve Yönlendirme" faktörleri ile birlikte anlamlılığını yitirmesi önemli bir bulgudur. Bu bulgu ișletmede sağlıklı bir beslenme ve egzersiz ortamı bulunması durumunda egzersize önem vermeyen çalıșanların dahi sağlık durumunun geliștiğini ortaya koymaktadır. Diğer bir ifade ile kurumsal düzenlemeler ve yönetimle ilgili yürütülen faaliyetler kișiyi kendi önceliklerinden daha fazla etkilemekte, egzersize önem vermeyen çalıșanlar dahi bu faaliyetlere iștirak ederek sağlık durumlarını geliștirmektedir. “İșletme çalıșanlarının sağlıklı beslenmeye verdiği önem” ise yeterli faktör düzeyi oluşturamadığı için buna ilișkin hipotez reddedilmiștir.

Tablo 16'da yapılan analizler sonucunda araștırmanın ana hipotezlerinin "kabul" veya "red" durumları özetlenmiștir.

Tablo 16:

Araștırmanın Hipotez Testi Sonuçları

\begin{tabular}{|c|l|c|}
\hline Hipotez No & \multicolumn{1}{|c|}{ Hipotezin İfadesi } & Sonuç \\
\hline $\mathbf{H}_{1}$ & $\begin{array}{l}\text { İșyeri ortamının sağlıklı beslenme ve fiziksel aktivite için uygunluğu ile çalıșan } \\
\text { sağlığı arasında ilișki vardır. }\end{array}$ & Kabul \\
\hline $\mathbf{H}_{2}$ & $\begin{array}{l}\text { İșletmenin sağlıklı beslenmeye verdiği önem ve yönlendirme ile çalıșan sağlığı } \\
\text { arasında ilișki vardır. }\end{array}$ & Kabul \\
\hline $\mathbf{H}_{3}$ & $\begin{array}{l}\text { İșletmenin fiziksel aktiviteye verdiği önem ve yönlendirme ile çalıșan sağlığı } \\
\text { arasında ilișki vardır. }\end{array}$ & Kabul \\
\hline $\mathbf{H}_{4}$ & $\begin{array}{l}\text { İșletme çalıșanlarının fiziksel aktiviteye verdiği önem ve yönlendirme ile çalı- } \\
\text { șan sağlığı arasında ilișki vardır. }\end{array}$ & Kabul \\
\hline $\mathbf{H}_{5}$ & $\begin{array}{l}\text { İșletme çalıșanlarının sağlıklı beslenmeye verdiği önem ve yönlendirme ile } \\
\text { çalıșan sağlığı arasında ilișki vardır. }\end{array}$ & Red \\
\hline
\end{tabular}


Çalıșanların sağlık durumları ile cinsiyetleri arasındaki ilișki t-testi kullanılarak incelenmiș ve analiz sonuçları Tablo 17'de sunulmuștur. Tablonun anlamlılık sütunundaki değerden ( $p=, 00 ; p<, 01)$ söz konusu değișkenler arasındaki ilișkinin istatistiksel olarak anlamlı olduğu anlaşılmaktadır.

Tablo 17:

Calıșanların Sağlık Durumu ile Cinsiyetleri Arasındaki İlișki

\begin{tabular}{|c|c|c|c|c|c|c|}
\hline \multicolumn{2}{|c|}{} & \multicolumn{2}{c|}{ Levene Testi } & \multicolumn{3}{c|}{ t-testi } \\
\cline { 3 - 7 } & F & Anlamlılık & t & df & Anlamlılık \\
\hline \multirow{3}{*}{$\begin{array}{c}\text { Sağlık } \\
\text { Durumu }\end{array}$} & $\begin{array}{c}\text { Varyansların Eșitliği } \\
\text { Varsayımı }\end{array}$ & 28,786 &, 000 & 6,187 & 399 &, 000 \\
\cline { 2 - 7 } & $\begin{array}{c}\text { Varyansların Eșitsizliği } \\
\text { Varsayımı }\end{array}$ & & & 5,798 & 266,994 &, 000 \\
\hline
\end{tabular}

Çalıșanların sağlık durumlarının cinsiyetlerine bağlı olarak değișimi ise Tablo 18'de sunulmuștur. Tablonun ortalama sütunundaki değerler kadınların algılanan sağlık șikâyeti puanlarının erkeklerin puanlarından daha yüksek olduğunu göstermektedir. Bu bulgu t-testi bulguları ile birlikte değerlendirildiğinde erkeklerin kadınlardan daha sağlıklı oldukları sonucuna ulașılmıștır.

Tablo 18

Çalıșanların Sağlık Durumunun Cinsiyetlerine Bağlı Olarak Değișimi

\begin{tabular}{|c|c|c|c|c|c|c|}
\hline & \multicolumn{2}{|c|}{ Cinsiyet } & N & Ortalama & Std. Sapma & Std. Hata \\
\hline \multirow{2}{*}{$\begin{array}{c}\text { Sağlık } \\
\text { Durumu }\end{array}$} & \multirow{2}{*}{ Dimension } & Kadın & 170 & 375,9235 & 341,82665 & 26,21691 \\
\cline { 3 - 7 } & & Erkek & 231 & 202,8139 & 217,15944 & 14,28804 \\
\hline
\end{tabular}

Çalışanların sağlık durumları ile medeni durumları arasındaki ilișki t-testi kullanılarak incelenmiș ve analiz sonuçları Tablo 19' da sunulmuștur. Tablonun anlamlılık sütunundaki değerden ( $p=, 25 ; p \rightarrow$,05) söz konusu değișkenler arasındaki ilișkinin istatistiksel olarak anlamlı olmadığı anlașılmaktadır. Bu bulgudan hareketle çalıșanların sağlık durumlarının medeni durumlarına bağlı olarak değișmediği sonucuna varılmıștır.

Tablo 19:

Çalıșanların Sağlık Durumu ile Medeni Durumları Arasındaki İlișki

\begin{tabular}{|c|c|c|c|c|c|c|}
\hline \multirow{2}{*}{} & \multicolumn{2}{|c|}{ Levene Testi } & \multicolumn{3}{c|}{ t-testi } \\
\cline { 3 - 7 } & F & Anlamlılık & t & df & Anlamlılık \\
\hline \multirow{3}{*}{$\begin{array}{c}\text { Sağlık } \\
\text { Durumu }\end{array}$} & $\begin{array}{c}\text { Varyansların Eșitliği } \\
\text { Varsayımı }\end{array}$ & 2,100 &, 148 & $-1,143$ & 399 &, 254 \\
\cline { 2 - 7 } & $\begin{array}{c}\text { Varyansların Eșitsizliği } \\
\text { Varsayımı }\end{array}$ & & & $-1,157$ & 388,340 &, 248 \\
\hline
\end{tabular}


Tablo 20:

Demografik Değișkenler İle İlgili Hipotezlerin Sonuçları

\begin{tabular}{|c|l|c|}
\hline Hipotez No & \multicolumn{1}{|c|}{ Hipotezin Ifadesi } & Sonuc \\
\hline $\mathbf{H}_{6}$ & Cinsiyet ile sağ ık durumu arasında ilișki vardır & Kabul \\
\hline $\mathbf{H}_{7}$ & Çalıșanların medeni durumu ile sağlık durumları arasında ilișki vardır. & Red \\
\hline
\end{tabular}

\section{Sonuç ve Öneriler}

Araștırmanın verilerinin analizinde elde edilen sonuçlar bu sektörde çalıșanların büyük bir bölümünün 30 yaș altında yer aldığını, bu grubun ardından da 31-40 yaș aralığında ki çalıșanların yer aldığını göstermektedir. Çok büyük bir çoğunluk üniversite mezunudur, çalıșanların yarıdan fazlası erkektir. Demografik özelliklere ilișkin bulgular çalıșanların çoğunluğunun milenyum kușağında, bir kısmının da X kușağında yer aldığını göstermektedir (Calabrese, 2010: 166). Dolayısı ile çalıșanların kent yașamını benimsemiș, sağlıktaki gelișmeleri takip eden, FA ve SB konularına duyarlı ve istekli oldukları düșünülmektedir. Araștırmanın yine bir diğer ilginç bulgusu da çalıșanların çok büyük bir çoğunluğunun ișveren destekli özel sağlık sigortasının bulunmasıdır.

Araștırmanın faktör analizi sonucunda elde edilen bulgular neticesinde ișyerinde fiziksel aktivite beslenmeye yönelik hizmetler bu hizmetlere ilișkin yürütülen yönetsel faaliyetler ve çalıșan sağlığı arasında bir ilișki kurulmaktadır. "İșletmenin egzersize verdiği önem ve yönlendirme”, "İșletmenin sağlıklı beslenmeye verdiği önem ve yönlendirme" “Iş̧letme çalışanlarının egzersize verdikleri önem” “isşyeri ortamının sağlıklı beslenme ve egzersiz için uygunluğu" șeklindeki bağımsız değișkenlerin çalıșan sağlığını ne düzeyde etkilediğini ortaya koymak adına olușturulan hipotezler ile korelasyon ve çoklu regresyon analizleri kullanılarak test edilmiștir. "İșletme çalıșanlarının sağlıklı beslenmeye verdiği önem ve yönlendirme" konusuna ilișkin sonuçlarda yeterli bir faktör olușumu belirlenememiștir.

Araștırmanın sonuçları ișletmelerin FA ve SB'e yönelik yönetsel faaliyetlerinin niteliklerini arttırdıkça çalıșan sağlığına ilișkin sonuçların daha olumlu olacağını destekler biçimdedir. Yönetsel faaliyetlerin niteliklerini arttıran faktörler birbirlerine kıyasla az veya çok çalıșan sağlığını etkiliyor olsa da bu faktörlerin her biri çalıșan sağlığına olumlu etkilerde bulunmaktadır. Bilișim sektöründeki ișletmelerin hizmetlerle ilgili yüksek maliyetlere katlanmadan önce hizmetlerin yönetimi ile ilgili ne gibi faaliyetler ve düzenlemeler yapmaları gerektiğini iyi belirlemeleri gerekmektedir. Dolayısıyla ișletmeler çalıșanların daha fazla zihin kullanmak zorunda olmalarını, masa bașında, hareketsiz daha fazla zaman geçirmek zorunda kalmalarını çalıșan sağlığı ile ilgili faaliyetleri yürütürken dikkate almalıdırlar. 
Araștırma aynı zamanda FA ve SB gibi çalıșan sağlığını geliștirici hizmetlere yönelik temel bir araștırmadır. Sonuçlar bu hizmetlerin sağlığa olumlu etkilerini desteklemekte, ileride yapılacak olan ve hizmetlerin verimlilik, prezenteizm ve örgütsel bağlılık gibiörgüt sorunlarına olan etkilerinin incelenebileceği araștırmalara bir temel olușturmaktadır.

\section{KAYNAKLAR}

Calabrese, John (2010) “Evolution Of Twenty-First Century Knowledge Workers" On The Horizon, 8(3), s.160-170.

Erdoğan, İrfan (2007) Pozitivist Metodoloji, 2.Baskı, Ankara: Erk.

Eriksen, Hege.; IhlabæK,Camila ; Ursin, Holger (2002) “Prevalence of Subjective Health Complaints in Norway", Scandinavian Public Health, 30(20),20-29.

Mazzola, Joseph J. (2010) Workplace Nutrition and Exercise Climate: Scale Development and Preliminary Model Test, Basılmamıș Doktora Tezi, Florida: Güney Florida Üniversitesi.

Mütercimler, Erol (2006) Geleceği Yönetmek ve Kazanmak lçin Stratejik Düşünme, İstanbul: Alfa.

Sağlık Bakanlığı (2010) Türkiye Obezite (SSișmanlık) Ile Mücadele ve Kontrol Programı 2010-2014, Ankara.

Stevens, James (2009) Applied Multivariate Statistics For The Social Sciences, New York: Taylor \& Francis Group.

Türker, Baș (2006) Anket Nasıl Hazırlanır? Uygulanır? Değerlendirilir?, Ankara :Seçkin. 


$$
\mid 108
$$

